\title{
Changes of the susceptibility of Staphylococcus aureus bacteria to the local therapeutic agent by using Nitrogen laser
}

Ayad. G. Anwer*

Date of acceptance
Rana R. Al-Ani*

$16 / 10 / 2008$

\begin{abstract}
This study involves the investigation of the effect of nitrogen laser with 337.1 $\mathrm{nm}$ wavelength on the sensitivity of Staphylococcus aureus bacteria by using local therapeutic due to burns.

Thirty six isolate of Staphylococcus aureus bacteria were isolated from 25 patients suffering from sever burns, each isolate of bacteria was irradiated with nitrogen laser at $(5,10,15$ and 30$)$ pulses/second repetition rates for $1,5,10,20$ and 30 minutes for each repetition rate.

The effects of nitrogen laser on the local therapeutics sensitivity of bacteria were obtained using Kirby Baur method.

Changes in the sensitivity of bacteria to local therapeutics (Tetracyclin, Chloramphenicol, Flumizin and Fucidin) occur at high repetition rate( 30 pulses/second) and for long exposure times (10, 20 and 30 minutes $)$ with $\left(2 \times 10^{-3}\right.$ $\mathrm{J} / \mathrm{cm}^{2}$ ) fluence.
\end{abstract}

Keywords: Staphylococcus aureus, Local therapeutic agent, Nitrogen laser, Susceptibility.

\section{Introduction}

Following a burn injury, the wound is a site with serious bacterial contamination and infection. Moreover, toxins released from bacteria concurrently will cause lesions to local wound as well as the whole body [1].

The most probable bacteria that infects burn wounds; are

Pseudomonas aeroginosa, Staphylococcus aureus, Escherichia coli

Bacillus spp and Bacteroids.

The multi resistant strains of $\mathrm{S}$. aureus play important role in contamination of burn wounds in the most burn care units [2].

The antibiotic resistance of $\mathrm{S}$. aureus has been depated in recent years; for example, increase the

resistance to methicillin was indicated in various hospitals in the world [3].

Resistance of $\mathrm{S}$. aureus to streptomycin, gentamycin and tetracycline has been increased after a few years of using them [4].

Laser reactions offer a new field of research. Laser is an expanding technological discipline in biology and medicine. It will ultimately contribute to a broad rapid expansion of both diagnostic and treatment procedures in microbiology, entomology, botany, immunobiology, cytofluorography, photobiology, and genetics $[5,6]$.

Understanding the mechanisms of laser tissue interaction is the basis for further development of diagnostic and therapeutic applications of lasers [5].

*Institute of Laser for Postgraduate Studies, University of Baghdad 
In sever burns; contamination with multi resistant Staphylococcus aureus bacteria is common and lead to inflammatory and septic effects.

Many studies have demonstrated the effects of laser radiation on pathogenic or opportunistic bacteria, since the introduction of laser in this field [6]. Bacteria in supragingival plaque samples, Streptococcus can be killed by (He-Ne) laser light with $632.8 \mathrm{~nm}$ wavelength in the presence of photosensitizer (TBO) [7].

Staphylococcus aureus bacteria can be killed after exposure to $11 \mathrm{~mW}$ Gallium aluminum arsenide laser for 300 seconds [8]. He-Ne laser with 35 $\mathrm{mW}$ and with prescence (Toluidine blue O)(TBO) makes Staphylococcus aureus bacteria susceptible to killing by the laser light within 30 seconds[9]. Inhibition of the phagocytic activity of polymorphnuclear leukocytes and the viability of bacteria were noticed after irradiation with nitrogen laser at high repetition rates pulsed (15 and 30 pulses/second) and for long exposure times (10, 20 and 30 minutes) [10].

In 2007 Al-Taie, shows that a noticeable changes in some biochemical characteristic of the Pseudomonas aeruginosa bacteria after irradiation with $\mathrm{N}_{2}$ laser at $(15,20$ and 30) minutes, the changes were more when the acridine orange as a photosensitizer was used [11].

The present study aims to investigate the effects of short wavelength N2 laser on sensitivity of Staphylococcus aureus to local therapeutics.

\section{Materials \& Methods Samples Preparation:}

The samples of bacteria were obtained from (25) patients suffering from sever burns, (10) of them were males and (15) were females, the age of patients ranges from 9- 56 years. These patients attending the burn and surgical units of two hospitals in Baghdad; Al-Yarmouk hospital and Al- Kindy hospital during the period from October 2001 until April 2001.

Sterile cotton swabs were used for taking the samples from the burning skin. The samples were transferred in cooled boxes to the laboratory, were then cultured on blood agar and nutrient agar.

\section{Isolation and Identification}

The isolates of bacteria were identified according to the microscopic examination \& the characteristics of the culture on the plates. The characteristics include the shape, color, hight, \& edges of the colonies in addition to the hemolysis zones on blood agar. Also, identification was attempted according to Biochemical tests [12].

Depending on Bergys Manual of Determinative Bacteriology [12], final identification of Thirty-six isolates of Staphylococcus aureus were obtained, using the following tests:

\section{1) Microscopic examination}

A smear of each isolated bacteria was stained using gram stain. Staphylococcus aureus bacteria appear after staining as gram positive, \& the cells were arranged as clusters [13].

2) Growth on mannitol Salts agar:

The isolates of bacteria were cultured on a mannitol salt agar (MSA). This media permits the selection of Staphylococci due to the high salt concentration of the medium. Since Staphylococcus aureus ferments manitol it can be distinguished due to the change in colour of the phenol red 
indicator in the medium from red to yellow [14].

3) Biochemical tests includes:-

A-Coagulase tests:

B- Catalase test:

C- Fermentation of sugars and acid production

The vials of ointment were obtained from Al-Razi Company. Types of locally therapeutics are listed in table (1)

Table (1) Types of local therapeutics.

\begin{tabular}{|l|l|l|}
\hline Local therapeutic & Basic material & Source \\
\hline Samacyclin & Tetracycline $3^{\circ} \%$ & SCD \\
(Ointment) & Chloramphenicol $1^{\circ} \%$ & SCD \\
Smsphenecol & Silver Sulphadiazine & SCD \\
(Ointment) & $1^{\%}$ & SCD \\
Flumizin (Cream) & Fucidic acid $2^{\circ} \%$ & \\
Fucin (Ointment) & & \\
\hline
\end{tabular}

Pulsed $\mathrm{N}_{2}$ - laser was used in this study. It is of Molectron UV 24-model. The laser emits radiation in the ultra violet region of the electromagnetic spectrum, $337.4 \mathrm{~nm}$.

It can be operated with repetition rate from 1 to 50 pulses per second. The pulse energy is $1 \mathrm{~mJ}$ with pulse duration of 10 nano second.

\section{Experimental Setups}

1) Bacterial samples preparation:

2) Irradiation procedures:

The samples of bacterial dilutions were subdivided into subgroups in epndrof tubes containing $0.5 \mathrm{ml}$ of bacterial suspension with three replicates for each sample, with exception the control group.

3) Effect of Nitrogen laser on the sensitivity of Staphylococcus aureus to local therapeutics:

For each of 36 isolate of bacteria, the sensitivity testes were done before and after irradiation with Nitrogen laser, as follows:

1- A pure colony of bacteria from a fresh culture were inoculated in $5 \mathrm{ml}$ of Muller-Hinton broth, that was incubated for 5-6 hr at a temperature of $37{ }^{\circ} \mathrm{C}$ to develop the turbidity.

2- Suspension of the bacteria was adjusted to a $0.5 \mathrm{McF}$ arland standard, which gives Absorbance of 0.10 at $600 \mathrm{~nm}$ wavelength, using spectrophotometer (Optima 2000).

3- The suspension of each isolate was irradiated with Nitrogen laser with a repetition rates of $5,10,15$ and 30 pulses/second and for exposure times of $(1,5,10,20$ and 30) minutes for each repetition rate with $\left(2 \times 10^{-3} \mathrm{~J} / \mathrm{cm}^{2}\right)$ fluence, the spot diameter of laser beam was $8 \mathrm{~mm}$.

4- After irradiation, the Muller-Hinton agar plates were inoculated by wetting a swab with bacterial suspension, the entire surface of the plate was swabbed in a number of different directions.

5- After 5 minutes of inoculation, a holes of $5 \mathrm{~mm}$ diameter and $3 \mathrm{~mm}$ of depth were done in the agar to put the local therapeutics.

6- The plates were incubated at $37^{\circ} \mathrm{C}$ for 18 to 24 hours.

7- After the incubation interval the zones of inhibition in plates of irradiated bacteria and control plates were measured (in $\mathrm{mm}$ ) with a ruler.

8- According to standard tables, the bacterial susceptibility were determined as resistant or sensitive or intermediate.

\section{Results \& Discussion}

The results show that four isolates of $S$. aureus bacteria exhibit noticeable change in their sensitivity to local therapeutics after exposure to nitrogen laser beam $30 \mathrm{P} /$ second repition rate for different exposure time, as it is illustrated in table (2). 
Table (2) Changing of Staphylococcus aureus Sensitivity to local therapeutics after irradiation with nitrogen laser

\begin{tabular}{|c|c|c|c|c|}
\hline Isolate & $\begin{array}{l}\text { Antibiotic or local } \\
\text { therapeutic }\end{array}$ & $\begin{array}{l}\text { Diameter of } \\
\text { Inhibition zone } \\
\text { (mm) before } \\
\text { irradiation }\end{array}$ & $\begin{array}{l}\text { Diameter of } \\
\text { Inhibition zone } \\
(\mathrm{mm}) \text { after } \\
\text { irradiation }\end{array}$ & $\begin{array}{c}\text { Laser parameters } \\
\text { (repetition rate \& } \\
\text { exposure time) }\end{array}$ \\
\hline $\mathrm{S}_{4}$ & Tetracycline & 7 & 20 & $\begin{array}{c}30 \mathrm{P} / \text { second } \\
10 \text { minutes }\end{array}$ \\
\hline $\mathrm{S}_{31}$ & Chloramphenicol & 8 & 25 & $\begin{array}{l}30 \mathrm{P} / \text { second } \\
30 \text { minutes }\end{array}$ \\
\hline $\mathrm{S}_{9}$ & $\begin{array}{l}\text { Flumizin } \\
\text { Fucidin }\end{array}$ & $\begin{array}{l}15 \\
20\end{array}$ & $\begin{array}{l}35 \\
25\end{array}$ & $\begin{array}{l}30 \mathrm{P} / \text { second } \\
20 \text { minutes }\end{array}$ \\
\hline $\mathrm{S}_{11}$ & Tetracycline & 8 & 26 & $\begin{array}{l}30 \mathrm{P} / \text { second } \\
20 \text { minutes }\end{array}$ \\
\hline
\end{tabular}

P: Pulses

1- Isolate $\left(\mathrm{S}_{4}\right)$ : this isolate is resistant to the local therapeutic tetracycline, figure (1) and exhibit sensitivity to this local therapeutic after irradiation with (30 pulses/second) repetitions rate and for 10 minutes exposure time, figure (2).

2- Isolate $\left(\mathrm{S}_{31}\right)$ : this isolate is resistant to the local therapeutic chloramphenicol before exposing to laser beam, figure (3). The sensitivity to this local therapeutic is noticed after exposure to laser beam with (30 pulses/second) repetitions rate and for 30 minutes exposure time, figure (4).
3- Isolate $\left(\mathrm{S}_{9}\right)$ : this isolate is resistant to the local therapeutics flumizin and fucidin before exposing to laser beam, figure (5). The sensitivity to these local therapeutics is noticed after exposure to laser beam with ( 30 pulses/second) repetitions rate and for 20 minutes exposure time, figure (6)

4- Isolate $\left(\mathrm{S}_{11}\right)$ : this isolate is resistant to the local therapeutic Tetracyclin before exposing to laser beam, figure (7). The sensitivity to this local therapeutic is noticed after exposure to laser beam with (30 pulses/second) repetitions rate and for 20 minutes exposure time, figure (8). 


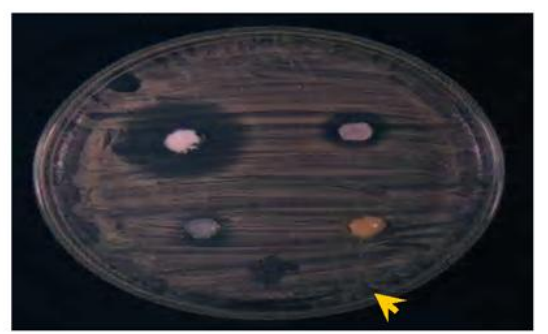

Figure (1). Photograph of sensitivity test for isolate (S4), resistance to the local therapeutic tetracycline before irradiation with nitrogen laser

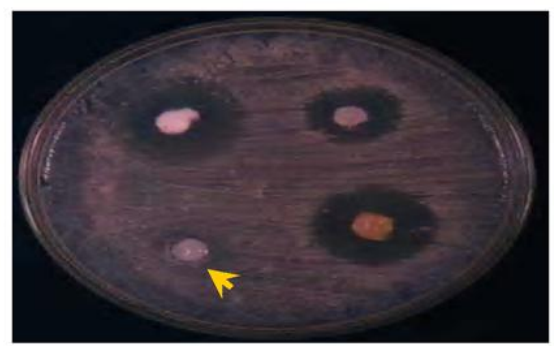

Figure (3). Photograph of sensitivity test for isolate (S31), resistance to the local therapeutic chloramphinecol before irradiation with nitrogen laser

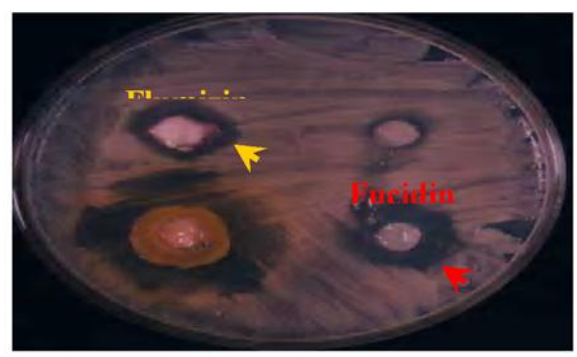

Figure (5). Photograph of sensitivity test for isolate (S9), resistance to the local therapeutic flumizin \& fucidin before irradiation with nitrogen laser

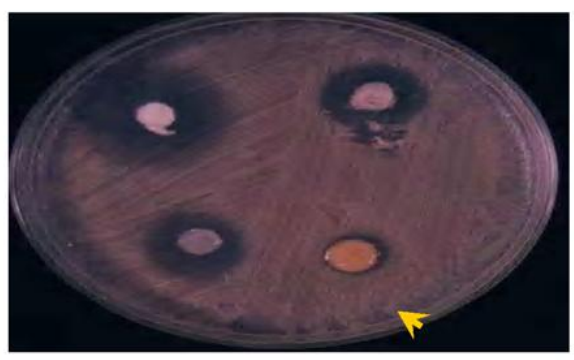

Figure (7). Photograph of sensitivity test for isolate (S11), resistance to the local therapeutic tetracyclin before irradiation with nitrogen laser

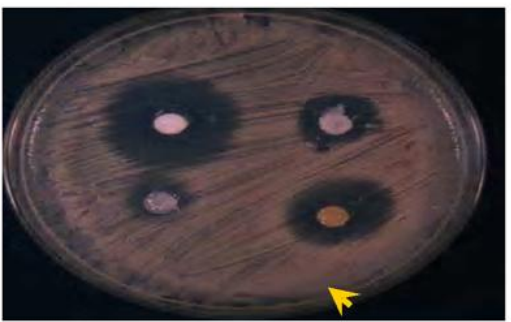

Figure (2). Photograph of sensitivity test for isolate (S4), sensetive to the local therapeutic tetracycline after irradiation with nitrogen laser $(30 \mathrm{p} / \mathrm{sec})$ repition rate for 10 minutes exposure time

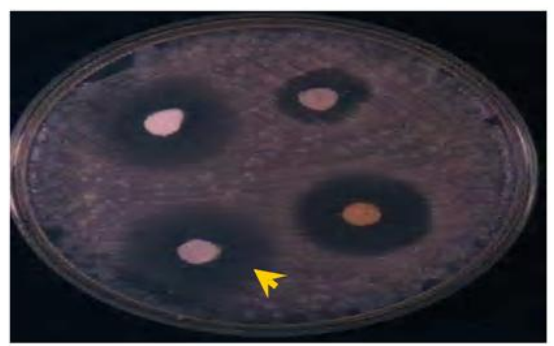

Figure (4). Photograph of sensitivity test for isolate (S31), sensetive to the local therapeutic chloramphinecol after irradiation with nitrogen laser $(30 \mathrm{p} / \mathrm{sec})$ repition rate for 30 minutes exposure time

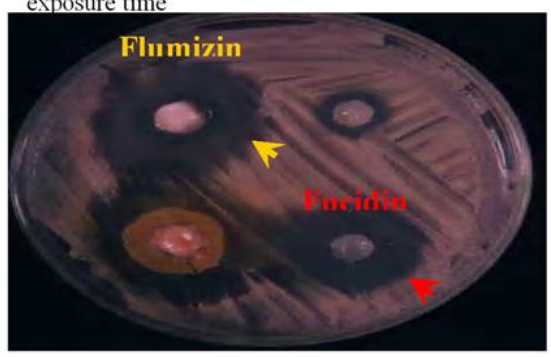

Figure (6). Photograph of sensitivity test for isolate (S9), sensetive to the local therapeutic flumizin \& fucidin after irradiation with nitrogen laser $(30 \mathrm{p} / \mathrm{sec})$ repition rate for 20 minutes exposure time

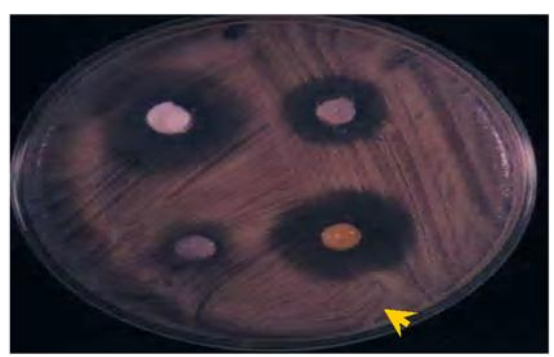

Figure (8). Photograph of sensitivity test for isolate (S11), sensetive to the local therapeutic tetracyclin after irradiation with nitrogen laser $(30 \mathrm{p} / \mathrm{sec})$ repition rate for 20 minutes exposure time

Unfiled Notes Page 5 
sensitivity, especially which that effect on protein synthesis in bacterial cells.

\section{References}

1. Woolfrey, B.F., 1981.An evaluation of burn wound quantitative microbiology.Am.J.Clin.Pathol.75: 532-537.

2. Cucchiara, P., Sucameti. M., Masellis, M., Torregrossa,V. and Valentino,L. 1994, .Bacteriological monitoring in a burns centere. Ann.Mediat.Burns Club., 7(2):96101 .

3. Lansing, P., John, H., and Donald, K. 1996, .Microbiology. McGrow Hill Co.USA. PP: 591-669.

4. Leclercq, R., Courvalin, P. 1991, Bacterial resistance to macrolids, lincosamide, and streptogramin antibiotics by target modification. Antimicrob. Ageents. Chemother . 35: $1267-1272$

5. Absten, T. Gregory and N. J. Joffe 1988, Laser in medicine an introductory guide. London.

6. Goldman, L. 1982. Applications of the laser. USA Pp: 155 - 171.

7. Wilson, M. 1995, Bacteria in superaging ival plaque samples can be killed by low power laser light in the prescence of a photosensitizer. J. Appl. Bacteriol., 78(5): 569-574

8. Wilson, M. and Pratten, J.1995, Lethal photosensitization of Staphylococcus aureus in vitro: effect of growth phase, serum, and preirradiation time. Laser-SurgMed., 16(3): 272-276. (Abstract).

9. Wilson, M. and Yianni, C. 1995, Killing of methicillin-resistant Staphylococcus aureus by low power laser. J. Med. Microbiol., 42(1): 62-66.

10. Ghazi, A. 2003,. Effect of $\mathrm{N}_{2}$ laser on phagocytosis, viability and antibiotics sensitivity of Staphylococcus aureus isolated from Burns. Ph.D thesis, Univ. of Baghdad.

11. Al-Taie, N. 2007, Effect of 337.1 $\mathrm{nm}$ and $805 \mathrm{~nm}$ lasers on the biochemical characteristics of Pseudomonas aeruginosa. M.Sc. thesis, Univ. of Baghdad.

12. Barret, J.T.1982, Text Book of Immunology : An introduction to immunochemistry and immunobiology. Fifth ED. Blackwellscience Ltd. Pp. 95-102.

13.Jawetz,E., Melnick, J.L., Adelberg, E.A., Brooks, F., Butel,J. 2001, Medical Microbiology. 22 ED. Churchill living Stone.London.PP: 197-203.

14. Stukus, P. 1997, Investigating microbiology "A laboratory manual for general microbiology". Harcourt Brace company. Pp: 193205.

15. Al-Kafajy,S.K. 2002, Astudy of the effect of photosensitization technique by low power $\mathrm{He}-\mathrm{Ne}$ laser on pseudomonas aeroginosa infecting burn wounds. M.Sc thesis. Univ. of Baghdad.

16. Peak, J., Peak, M. and Tuveson, R. 1983, Ultraviolet action spectra for aerobic and anaerobic inactivation of Escherichia coli strains specifically sensitive and resistance to near UV radiations. Photochem. Photobiol. 38(5): 541-543.

17. Hanson, K.M. and Simon, J.D. 1998, Epidermal trans-Urocanic acid and the UV-A-induced photoaging of the skin. Proc Natl. Acad Sci USA. September 1; 95(18): 10576-10578.

18. Montagnoli, G. 1977, Biological effect of light on proteins: Enzyme activity modulation. Photochem. Photobiol., 26: 679-683. 


\section{Staphylococcus التغير في استجابة بكتريا المكورات العنقودية الذهبية aureus}

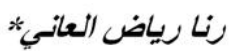

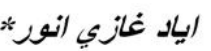

يتضمن البحث دراسة تأثير الثعة ليزر النتروجين بالطول الموجي 337.1 نانوميتر على استجابة بكتريا

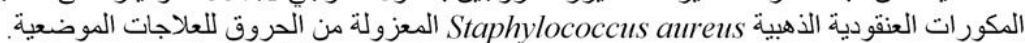

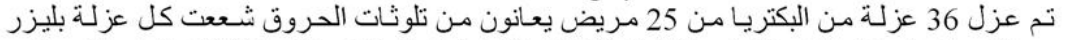

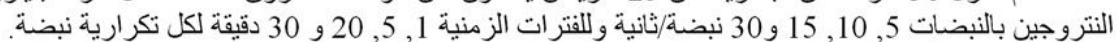
تم تقدير تأثير الليزر على استجاية البكتريا للعلاج الموضعي بأستخدام طريقة قياس اقطار منطقة التثبيط

Kirby-Baur Method

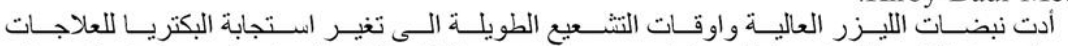

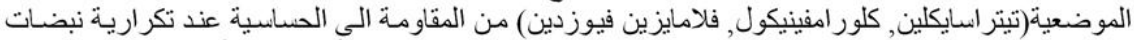

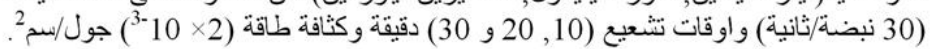

